\title{
Effects of equipments and processing conditions on quality of fresh-cut produce
}

\author{
Francisca Aba Ansah, Maria Luisa Amodio, Maria Lucia Valeria De Chiara, Giancarlo Colelli \\ Dipartimento di Scienze Agrarie, degli Alimenti e dell'Ambiente, Università di Foggia, Italy
}

\begin{abstract}
A wide range of fresh conveniently packaged, minimally processed products are available on both local and global market in response to consumer demand for ready to eat food. Majority of these products are leafy vegetables, which are highly susceptible to quality changes during minimal processing operations (trimming, cutting, washing, drying, and packaging). Despite the available precautionary measures for maintaining quality attributes of raw and processed material, quality degradation due to minimally processing is unavoidable, also considering that a peeling, trimming and/or cutting operation is always present except than for baby leaves and small fruits. In addition, other operations as washing and drying are known to cause mechanical stresses and loss of sugars and nutrients. However, the extent to which quality is compromised depends on the produce and on the processing conditions, including equipment and their operational settings. This review aims to describe the main processing operations and equipment used, resuming the available information on their impact on final quality of fresh-cut products over storage, in order to identify areas for future research aiming to the enhancement of product quality.
\end{abstract}

\section{Introduction}

A variety of conveniently packaged, lightly processed fresh products also known as minimally-processed or fresh-cut products are available on the market in response to a worldwide consumer demand for ready to eat food. Majority of these products, highly susceptible to quality changes during minimal processing activities (trimming, cutting, washing, centrifugation or drying of sur-

Correspondence: Maria Luisa Amodio, Dipartimento di Scienze Agrarie, degli Alimenti e dell'Ambiente, Università di Foggia, via Napoli 25, Foggia 71122, Italy.

E-mail: marialuisa.amodio@unifg.it

Key words: Machinery; cutting; washing; drying; packaging.

Received for publication: 18 December 2017.

Accepted for publication: 2 February 2018.

(C) Copyright F.A. Ansah et al., 2018

Licensee PAGEPress, Italy

Journal of Agricultural Engineering 2018; XLIX:827

doi:10.4081/jae.2018.827

This article is distributed under the terms of the Creative Commons Attribution Noncommercial License (by-nc 4.0) which permits any noncommercial use, distribution, and reproduction in any medium, provided the original author(s) and source are credited. face water), are represented by leafy vegetables, although an increasing share of the market is also represented by fruit-based convenience product. Processing and handling of fresh produce at appropriate low temperature, relative humidity, optimum atmosphere storage and suitable packaging, protect their color, texture, flavor and nutritional attributes (Paull, 1999; Kader, 2002). Despite the available precautionary measures for maintaining quality attributes as mentioned, alteration of physiological processes of the produce during minimal processing is unavoidable. However, the extent to which quality is compromised depends on the produce and on the processing conditions. Produce characteristics include the type of crop (tissue, organ and its composition), respiration rate, time of harvest, maturity stage and any pre-processing treatment it may have been subjected to prior processing. The processing conditions include the temperature in the facility, water quality, used sanitizer, equipments used during processing, and packaging solutions. Therefore, understanding the changes that occur during minimal processing and how each processing activity and equipment used contribute to product stress and quality loss will aid to improve minimal processing and product quality.

This review aims to describe the main processing operations and equipments used, resuming the available information on their impact on final quality of fresh-cut products over storage, in order to identify areas for future research aiming to the enhancement of product quality. Main research paper and some specific review are included in Table 1.

\section{Influence of minimal processing operations/equip- ment on quality changes}

The equipments required for minimal processing of fresh produce perform different functions during the various processing steps (i.e. de-coring, peeling, cutting, shredding, washing, drying, etc.), influencing the final quality of the product. Each step operations may alter the integrity of the raw material, especially in the cut products, making them more prone to deterioration (Sanz et al., 2002). Also, different unit operations may provide opportunities for cross-contamination, as a small lot of contaminated product may affect a large lot during the processing steps (Gil et al., 2015). In addition due to leaching of nutrients and exudates, it is important to process different leafy vegetables in different processing lines or to carefully clean the lines before changing product. A classic example is with cabbage, which releases a high concentration of organic nutrients into washing water during processing (Cantwell and Suslow, 1999).

The main risk factors for product quality and safety are related to the temperature during processing, water quality and sanitation, hygienic design and hygienic status of equipments, as well as employee hygiene and training (Castro-Ibáñez et al., 2016). The main minimal processing steps and the effects of the various 
Table 1. Overview of existing literature on the effect of different operation ster.

\begin{tabular}{|c|c|c|c|}
\hline Processing step & Object of the study & Produce/Material & Reference \\
\hline Cutting & $\begin{array}{l}\text { Cutting mode (number of cuts) } \\
\text { Cutting mode (type of cut) } \\
\text { Mechanical slicing (SammicCA300, Barcelona, Spain) } \\
\text { Waterjet and blade-cut }\end{array}$ & $\begin{array}{l}\text { Bobby Beans } \\
\text { Cantaloupe Melon } \\
\text { Carrots } \\
\text { Eggplant } \\
\text { Fresh-cut vegetables } \\
\text { Banana } \\
\text { Lettuce } \\
\text { Carrots } \\
\text { Lemons } \\
\text { Pumpkin } \\
\text { Radish } \\
\text { Melons } \\
\text { Lettuce } \\
\text { Lettuce }\end{array}$ & $\begin{array}{l}\text { Grout et al., } 2002 \\
\text { Portela and Cantwell, } 2001 \\
\text { Barry-Ryan and O'Beirne, } 1998 \\
\text { Mishra et al., } 2012 \\
\text { O'Beirne, 1995 } \\
\text { Abe et al., 1998 } \\
\text { Deza-Durand and Petersen, } 2011 \\
\text { Surjadinata and Cisneros-Zevallos, } 2003 \\
\text { Artés-Hernández et al., } 2007 \\
\text { Lee et al., 2008 } \\
\text { Saavedra del Aguila et al., } 2006 \\
\text { Aguayo et al., 2004 } \\
\text { Barry-Ryan and O'Beirne, } 1999 \\
\text { Wulfkuehler, et al., 2014; Cantwell et al., } 2016\end{array}$ \\
\hline Washing/Cutting & Water jet cut and Sanitizer comparison & Watermelon & Mcglynn et al., 2003 \\
\hline Washing & $\begin{array}{l}\text { Sanitizer comparison/washing mode } \\
\text { Washing mode } \\
\text { Additional sanitizing treatments } \\
\text { Additional sanitizing treatments/Sanitizer comparison }\end{array}$ & $\begin{array}{l}\text { Cabbage, iceberg lettuce and leek } \\
\text { Carrots } \\
\text { Escarole and lettuce } \\
\text { Lettuce } \\
\text { Red chard } \\
\text { Rocket leaves } \\
\text { Spinaches } \\
\text { Potato } \\
\text { Fresh-Cut fruit and vegetables } \\
\text { Leafy vegetables } \\
\text { Lettuce } \\
\text { Artichoke and borage } \\
\text { Peppers } \\
\text { Baby Leaf Brassica } \\
\text { Lettuce } \\
\text { Carrots }\end{array}$ & $\begin{array}{l}\text { Vandekinderen et al., } 2009 \\
\text { Gonzalez et al., } 2004 \\
\text { Allende et al., } 2008 \\
\text { Baert et al., 2009; López-Gálvez et al., } 2009 \\
\text { Tomás-Callejas A et al.,2012 } \\
\text { Martínez-Sánchez et al., } 2006 \\
\text { Gómez-López et al., } 2013 \\
\text { Beltrán et al., 2005 } \\
\text { Vandekinderen et al., 2007; Gil et al., } 2009 \\
\text { Kim et al., 2016 } \\
\text { Luo et al.,2011; Lopez-Fernandez et al., } 2013 \\
\text { Sanz et al., 2002 } \\
\text { Toivonen and Stan, } 2004 \\
\text { Martínez-Sánchez et al., } 2008 \\
\text { Kim et al., 1999 } \\
\text { Gómez-López et al., } 2007\end{array}$ \\
\hline Washing/Packaging & Washing mode/gas optimization & Rocket Leaves & Rux et al., 2017 \\
\hline Drying & Centrifugation time & Carrot & Moretti et al., 2007 \\
\hline Packaging & Gas optimization & $\begin{array}{l}\text { Artichoke } \\
\text { Basil } \\
\text { Broccoli raab } \\
\text { Carrots } \\
\text { Coconut } \\
\text { Fennel } \\
\text { Fresh-Cut fruit and vegetables } \\
\text { Mushrooms } \\
\text { Lettuce } \\
\text { Mushroom, celeriac and chicory endive } \\
\text { Peaches } \\
\text { Pumpkin } \\
\text { Rocket leaves } \\
\text { Strawberry } \\
\text { Zucchini flowers }\end{array}$ & $\begin{array}{l}\text { La Zazzera et al., } 2012 \text { and } 2015 \\
\text { Amodio et al., 2005 } \\
\text { Cefola et al., 2016a } \\
\text { Izumi et al., 1996; Amanatidou et al., } 2000 \\
\text { Amodio et al., 2004 } \\
\text { Rinaldi et al., } 2010 \\
\text { Gorny, 2003 } \\
\text { Capotorto et al., 2015 } \\
\text { Mateos et al., 1993; Oliveira et al., 2010; } \\
\text { Baldassarre et al., 2013; Ansah et al., } 2015 \\
\text { Jacxsens et al., 2001 } \\
\text { Colantuono et al., 2015 } \\
\text { Amodio et al., 2010 } \\
\text { Cornacchia et al., 2006; Amodio et al., 2015; } \\
\text { Inestroza-Lizardo et al., 2016; } \\
\text { Mastrandrea et al., 2017b } \\
\text { Almenar et al., 2007 } \\
\text { Cefola et al., 2016b }\end{array}$ \\
\hline & $\begin{array}{l}\text { Gas optimization/chemical preservative } \\
\text { Gas optimization/temperature } \\
\text { Peelability optimization } \\
\text { Seealability optimization } \\
\\
\text { Vertical-Form-Fill-and-Seal Machines } \\
\text { with biodegradable film }\end{array}$ & $\begin{array}{l}\text { Pears } \\
\text { Baby Spinach } \\
\text { Adhesive, cohesive and delamination films } \\
\text { LLDPE } \\
\text { Lettuce }\end{array}$ & $\begin{array}{l}\text { Gorny et al., } 2002 \\
\text { Kou et al., } 2014 \\
\text { Baker, 2009 } \\
\text { Mueller et al., 1998; Lim, } 2012 \\
\text { Mihindukulasuriya and } \\
\text { Brown et al., } 2009\end{array}$ \\
\hline Entire process & $\begin{array}{l}\text { Equipment requirements } \\
\text { Process design, facility and equipment requirements } \\
\text { Process design, facility and equipment requirements }\end{array}$ & $\begin{array}{l}\text { Fresh-cut fruit } \\
\text { Fresh-cut fruit and vegetable } \\
\text { Fresh-cut fruit and vegetable }\end{array}$ & $\begin{array}{l}\text { Turatti, } 2015 \\
\text { Turatti, } 2011 \\
\text { Artés and Artés } \\
\text { Hernández, } 2003\end{array}$ \\
\hline
\end{tabular}


equipments used for fresh-cut processing are discussed in detail in the subsequent section. Particularly only the steps directly involved in manipulation of the product will be discussed, omitting phases as product grading and classification for which an extensive review is already published (Giovenzana et al., 2015). Figure 1 depicts the mostly practiced minimal processing steps and product handling operations for fresh-cut processing.

\section{Cutting}

Cutting or size reduction is an important step in the preparation of fresh-cut fruits and vegetables. Moreover peeling and trimming may be also additional operations, which also induce the same kind of damage to the tissues. Rotating blades are used for leafy and some fruit vegetables, whereas more complex and species-specific

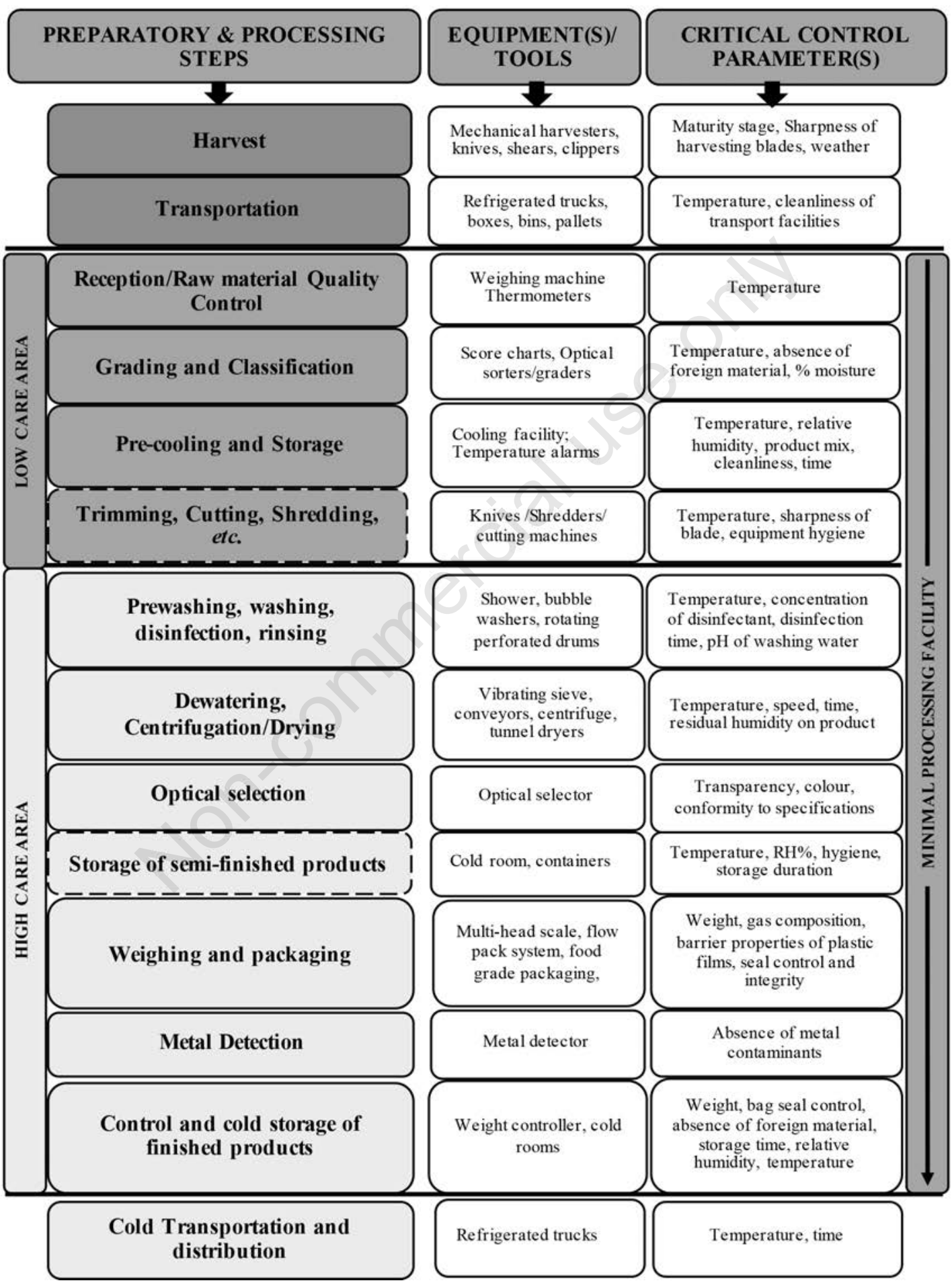

Figure 1. Minimal processing steps, equipments used and quality control parameters; processing steps encircled with broken lines may be optional. Adapted from Artés-Hernández et al., 2013. 
cutting machines are used for fruits. The choice and type of cut depend on the intended use of the product in relation to the commercial standards; moreover, the level of machinery automation may vary from very low (i.e. manual operation) to very high, particularly for fresh-cut fruit processing. Peeling may be achieved via chemical, mechanical or high-pressure methods, but the mechanical method is the most used. Manual peeling machines for fruits consist of a cylinder blade, which, after applying a manual pressure, cut the external ring of the fruits including the skin. Other simple and discontinuous peeling machines make the fruits rotate while a mobile arm equipped with a vertical blade removes the skin. This is also the principle adopted for automatic machines where the fruits are well oriented before peeling and subsequently cut; these machines may process from 5 to 30 fruits per minute. In discontinuous lines, or in flow-chart where peeling is not required, knives of different kinds, or dicers, slicers, choppers, and shredders are used for further size reductions, exerting different forms of stresses and injuries on cut products. Different slice height and piece dimensions may generally be achieved by regulating the blade distance or changing the cutting accessories. All these processes break the surface epidermal layer and may ruin cell integrity in deeper tissues of produce, causing an increase in respiration, a release of phytonutrients while exposing the product surface to microbial contamination. The limitations related to these processing steps include, desiccation, microbial spoilage, browning of tissues, discoloration, development of off-flavour and taste defects (Bansal et al., 2015).

Several studies have reported the effects of cutting on fresh-cut produce.Wound-induced respiration rate increased with the number of cutting as for whole, half, sliced potato and potato sticks (Gorny 2003), or for shredded and sliced radicchio (Saavedra del Aguila et al., 2006), and particularly with increasing of the ratio of cut surface area by the tissue weight as shown on carrots (Surjadinata and Cisneros-Zevallos, 2003). Moreover some authors also observed different responses of cut pieces to the atmosphere composition, reporting that the reduction of respiration induced by controlled atmosphere storage was greater in slices or sticks than in shredded carrots (Izumi, et al., 1996).

Aguayo et al. (2004) also found that melons cut in cylinders exhibited more translucency after 10 days storage compared to slices and trapezoidal cuts. In addition cutting may cause the release of exudates that provide nutrients to promote the growth of enteric pathogens (Matthews, 2013). Notably, this step is a critical point that requires processing line hygiene. Equipments used for cutting need to be cleaned, disinfected and sharpened at regular intervals every working day to avoid the build-up of organic residues and microbial contaminants, as well as to reduce damage caused to the product (CAC, 2003; FDA/CFSAN, 2008).

Barry-Ryan and O'Beirne (1998) showed the effect of blade sharpness on the severity of physical damage, physiological stress and microbial growth of a commodity as razor blade $<$ sharp machine blade $<$ blunt machine blade (razor blade cause the least damage). In confirmation, fresh-cut carrots prepared with sharp cutting blades showed reduced wound response, lignin accumulation, white blush, softening, and microbial growth (Barry-Ryan and O'Beirne, 1998); melon pieces cut with a sharp blade exhibited less ethanol concentrations, off-odor, and electrolyte leakage compared to pieces processed with a blunt blade (Portela and Cantwell, 2001). Though the level of sharpness was not quantified, Grout et al. (2002) reported that maintaining cutting knives at a high level of sharpness, delayed the onset of enzymatic browning on sliced green beans by up to one day in cold storage. The use of new knife blades, in fact, caused less damage compared to used and sharpened blades which induced red discoloration and whitening dehydration on cut romaine lettuce after 12 days in air at $2.5^{\circ} \mathrm{C}$ (O’Beirne, 1995).

Furthermore, scanning electron and fluorescence microscopic imaging showed that sharp blade cutting (thickness, $0.04 \mathrm{~mm}$ ) of eggplants caused less physical injury and cell death, compared to conventional knife (blade thickness about $0.25 \mathrm{~mm}$ ); particularly a reduction of phenolic leaks and of polyphenol oxidase activity was observed wich resulted in lesser browning (Mishra et al., 2012). Moreover the effect of cutting type and intensity may still be observed on quality and composition of cut produce after storage. It has been shown that increasing the number of cutting increased metabolic activity and decreased sensorial evaluation of sweet pumpkins (Lee et al., 2008), and reduced flavor and phytochemical content of cut lemons (Artés-Hernández et al., 2007). In a recent work the effect of the wounding intensity was studied on strawberries, which were cut into 4, 16, 64, 128 pieces and chopped. Results showed that respiration rate increased with wounding intensity up to the level of 64 pieces compared to whole fruits and then decreased in the chopped samples, in which the damage compromised cell functionality. The extent of loss of ascorbic acid in iceberg lettuce has also been attributed to the cutting method and sharpness of the blade; machine and manually slicing caused a lower retention of ascorbic acid than manual tearing on cut iceberg lettuce (Barry-Ryan and O'Beirne, 1999).

Besides sharpness, the type of blade itself and equipment used may also influence cutting quality. Fresh-cut lettuce processed with sharp rotating blades was reported to have lower respiration rates and microbial counts during storage than those cut with sharp stationary blades (O'Beirne, 1995). Some authors also recommended food grade water-jet cutting to have superior cutting quality (in terms of product visual quality and discoloration) than blade cutting (Cantwell et al., 2016), but literature is scarce and contradictorial. McGlynn et al. (2003), found that water jet cut melon were darker but firmer than kinfe-cut pieces, whereas Wulfkuehler et al. (2014) did not find any difference in terms of microbial, physiological and sensorial quality of fresh-cut lettuce cut with water jet compared to blade cutting.

Despite the effects of the cutting equipment, the severity of the cutting may also be influenced by the direction and may vary from product to product. However, research work with regards to cutting direction is not very extensive. Abe et al. (1998) reported that longitudinal cut direction produced banana slices that browned and softened rapidly and with higher respiration rate than those cut in the transverse direction. On the contrary, Deza-Derund and Petersen (2011), assessing the impact of cutting direction on respiration rate and volatiles formation, reported that transverse cutting of lettuce through the mid-rib was a more severe method of preparation, which stimulated volatiles of the lipoxygenase pathway, while longitudinal cutting enhanced formation of volatiles from other metabolic routes.

Generally, selecting the right type of blade, using sharp blades and reducing the extent of tissue damage would minimize quality losses, provided temperatures are low enough to minimize respiration and metabolism.

\section{Washing}

Washing has the objective to remove foreign material, soil, dust and any agrochemical residues weakly bound to the surfaces of whole or cut products (Lopez-Fernandez et al., 2013). Moreover washing is considered as the primary step for reducing the total microbial count of the product (Allende et al., 2008) before it is packaged although, if not done properly, cross-contamination may 
occur (Olaimat and Holley, 2012). Usually washing systems in the fresh-cut industry are made up of three washing phases: the first two taking place in 2 adjacent tanks, while the third, namely a rinsing phase, is usually carried out through a showering system. However, depending on the product and operating conditions of a company, the washing phases in tanks could also be single or double with various wash and spray combinations (Luo, 2007). Figure 2 depicts a typical washing system in the minimal processing industry. This washing system is sometimes termed as jacuzzi due to the produced bubbling action. Water and product normally flow in opposite directions, with the purity of the water-decreasing passing from last to first washing tank.

The first wash removes all dirt, soil and debris combining in most of the case both the shower and water immersion.

Water in this tank increases rapidly in microbiological load, requiring an implementation of a filtration and a refreshing water system that respects the product-to-water ratio, and application of a disinfecting agent to keep the microbial load of the water to a low level (López-Gálvez et al., 2010; Holvoet et al., 2012). A second wash is then performed in the following tank. At this phase, any microbiological load on the product is further decreased; however, cross-contamination within a lot or among lots may occur (Luo et al., 2011). In this same tank, sanitation of the product takes place and the water is treated with a chemical agent to reduce microbial load and prevent cross-contamination during washing (SolivaFortuny and Martin-Belloso, 2003). The turbulence or force of flowing wash water on produce surface mainly promotes the mechanical removal of microorganisms; however, it may also cause slight structural damage to soft leafy vegetables. Besides, in cut products the surface may absorb wash water, making disinfection very critical to prevent contamination (Cantwell and Suslow, 1999). Despite the quantity, the quality of water used in washing whole products impacts on the effectiveness of washing (Allende et al., 2008; López-Gálvez et al., 2009). Moreover, conveyors used to transport fresh-cut products to the washer and from washer to the dryer are known to be one some of the hotspots for microbial contamination (Buchholz et al., 2012).

The third and last washing phase before packaging is the rinsing step, which requires very low or, most frequently, no dose of disinfecting agent to achieve good results. Other commercial operations also adapt open and closed-flume systems (Luo, 2007). Recently, a patented system which has adapted the closed pipe flume concept, have been introduced to wash fragile and delicate products, such that contact time with sanitizing water solution is precisely controlled for full immersion and appropriate treatment time (Turatti, 2015). This has been recommended as it does not remove the bloom of blueberries and may be applicable for delicate baby leaf vegetables. Other washing systems including ozone washers which operate either by a rotational movement to stir washing water or by mid-range ultrasonic waves to produce bubbles, have been proposed (Kim et al., 1999).

Chlorine is the most used among sanitizer. It is relatively easy to use, low cost and is able to prevent pathogen cross-contamination of produce during washing (López-Gálvez et al., 2009; Luo et al., 2011). However, the potential generation of trihalomethanes (THMs), when chlorine or chlorine-based sanitizers are used, may

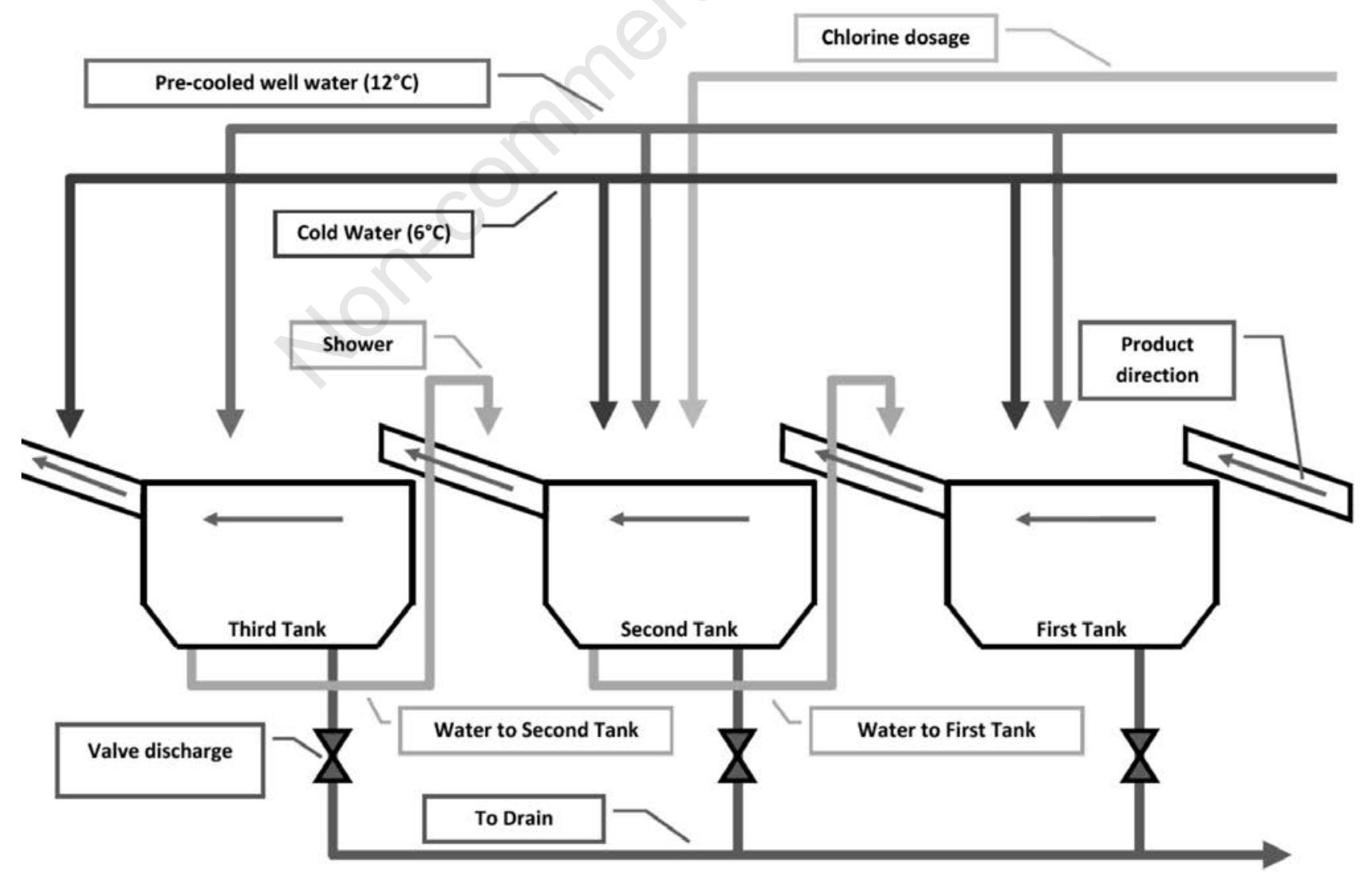

Figure 2. A typical washing system in the minimal processing industry. 
present health hazards, although recent studies have reported that total THM levels in the vegetable tissue were below the detection limit (Gómez-López et al., 2013). Moreover, chlorine-based sanitizers, used under optimal conditions, should not represent a high risk of THM formation (Artés-Hernández et al., 2013). Chlorinated water used for disinfection, has also been found to be effective in removing pesticide residue on the surface of fruits and vegetables (Bajwa and Sandhu, 2014). Nonetheless, loss of pesticide residues on the surface of leafy vegetables is dependent on the solubility of the pesticide in water as described for diethofencarb on crown daisy leaves during washing with stagnant and then running water (Kim et al., 2016). The use of sanitizers alternative to chlorine, as peroxyacetic acid (among the most promising), have been studied as reported in several works (Gonzalez et al., 2004; Gómez-López et al., 2007; Baert et al., 2009; Gil et al., 2009; Vandekinderen et al., 2009).

The washing and cooling of products directly after cutting reduces respiration and minimizes the injury responses by removing sugars, stress-related compounds like acetaldehyde, phenols and other nutrients on the cut surfaces that may also favor microbial growth and tissue browning or discoloration (Cantwell and Suslow, 1999; Toivonen and Stan, 2004). Also, the unknown signal elicited by wounding which initiates tissue degradation might be removed by washing (Cisneros et al., 2014).

To prevent internalization and infiltration of bacteria, wash water temperature should not be much lower than product temperature (Sapers, 2003), as it could cause a negative temperature differential and a partial vacuum, due to gas volume reduction, that will draw in water, through the natural fruit cavities (pores or even cut surfaces), causing possible chemical or microbial contamination (Sapers, 2003). This is particularly true for products characterized by fairly large dimensions (i.e. melons, pineapples). Wash water temperature should be about $5^{\circ} \mathrm{C}$ higher than the internal temperature of the product to prevent the water suction effect (Hernandez-Brenes, 2002; Nicola et al., 2009). Temperature gap between the produce and the water temperature could be minimized by air-cooling prior to washing (Nicola et al., 2009).

Most of the research studies on the use of sanitizer during washing have focused on microbial quality and reduction, with very little information about the effect on phytonutrients (Beltran et al., 2005; Martínez-Sánchez et al., 2006). Vandekinderen et al. (2007) reported that the use of peroxyacetic acid (Chriox 5) led to a loss of total vitamin $\mathrm{C}$ content varying from 15 to $25 \%$. However, rinsing fresh-cut vegetables with water is already known to cause a loss of total vitamin $\mathrm{C}$ of about $20 \%$, due to its hydrophilic properties. On the other side, decontamination with potable water or sodium hypochlorite (20 and $200 \mathrm{mg} \mathrm{L}^{-1}$ ) did not lead to a decrease in alpha- and beta-carotene (not water soluble) of freshcut carrots (Vandekinderen et al., 2007).

The oxidative action of disinfectant, coupled with bubble action of the washer may also cause browning or loss of green color on the whole un-cut surface of leaves during storage. Optimizing washing operations could also help to reduce these effects.

\section{Drying}

After washing, removal of gained moisture on the produce surfaces is done using several systems, which include draining devices, centrifugal spin dryers, vibrating racks, rotating conveyors, hydro sieves, forced air and spin less drying tunnels (Gorny et al., 2002). Centrifugation or spin-drying is widely used in the fresh-cut industry, although other methods such as vibration screen and forced air tunnel have also been adopted for water removal
(Moretti et al, 2007). Vibratory conveyors are used for dewatering of leafy vegetables (i.e. removing excess of water from the surface of the produce) before they enter thorough the drying systems, represented by centrifuges/spin dryers. Surface drying on the conveyor belt is achieved through forced chilled air circulating over a perforated belt as in the use of air-bed conveyors which are widespread across Europe and the United States, although their efficiency to dry high volumes should be optimized (Artés and ArtésHernández, 2003; Turatti, 2011). Excessive centrifugal force not only removes water, but it may also crack and deform produce tissues hastening senescence (Ahvenainen, 2000). Liquid losses due to the damaged cells may also affect sensorial attributes like visual quality, taste and texture. It is therefore important to optimize speed and time requirements suitable for specific products to reduce quality losses during the process. Liquids removed from cell leakages during the drying process can support microbial growth and enzyme activity; populations of Salmonella were recovered from centrifugation discharge indicating this step as potentially hazardous for cross-contamination (Artés-Hernández et al., 2013). Research suggests that effluent water discharged by centrifugation represents a potential risk of cross-contamination to product and equipment prior to packaging (Tomás-Callejas et al., 2012). For leafy vegetables like lettuce, removal of more moisture (i.e., slight desiccation of the product) may favor longer post-processing life (Cantwell and Suslow, 1999). This may also be true for rocket leaves as controlling the development of off-odors in packaged washed leaves during storage was related to the critical need for the complete removal of free water during the drying step (Rux et al., 2017).

Several studies have been published on the effect of drying systems on the nutritional quality of dried vegetable products, however, there are very few studies on the effect of drying operations on the content of phytonutrients in fresh-cut products. Although it has been reported that the retention of nutritional properties of leafy greens is higher at a faster drying rate (Negi and Roy, 2001), the extent to which drying dynamics affect the product quality is unknown. In air-tunnel drying systems, heated dry air absorbs moisture from the product, which then passes through a cooling unit, which blows cold air. Though the heated air is applied for a short period, high temperatures may induce several irreversible biological or chemical reactions, which may cause modifications in color, a decrease of sensory quality, and losses of nutrients, aroma and texture (Abid et al., 1990). Despite this, if drying is done under controlled conditions with cold air, then the fresh properties of the product can be maintained (Nagaya et al., 2006); the only limitation is that the air-dryers have low efficiency to dry high volumes of product (Artés-Hernández et al., 2013).

The use of predictive models like the multiphase transport model can be adapted to aid in improving drying efficiency as it is capable of predicting actual drying rates, operating conditions and it assures the absence of critical wet areas on product surfaces for microbial spoilage (Curcio et al., 2016). Other drying techniques that may be adapted include the use of low humidity air dryers, infrared air dryers (where infrared is used as the heat source) and radio frequency dryers (Naidu et al., 2016), which are also reported to minimize chemical degradation and nutrient loss (Van Loey et al., 2005).

\section{Packaging}

This is the final step of minimal processing. At this step, optimum packaging conditions depend on the characteristics of the fresh-cut fruit or vegetable and its packaging material requirements for manual or automated operations. The selection of an 
ideal packaging material for each product will depend among other factors on the kind of package (rigid tray, semi-rigid lidded tray or flexible bag); barrier properties (oxygen, carbon dioxide, and water vapour transmission rates); physical attributes of the film (clarity, durability, stretch capability, thickness, machinabilityresistance to tearing, puncture); sealing reliability-precision and integrity of heat sealing or closure, antifog properties; absence of toxicity and interaction with the product; resistance to chemical degradation; printable, economical and commercial suitability of the film (Mangaraj et al., 2009). Fresh-cut products are both weighed and packaged directly or temporarily stored $(0-12 \mathrm{~h})$ in a cold room prior to packaging.

Active modified atmosphere packaging (MAP) is aimed to rapidly substitute air with the desired gas composition by gas-flushing with addition of nitrogen and $\mathrm{CO}_{2}$ to speed up the achievement of the equilibrium. Passive MAP on the other hand is developed by the only interaction of packaging film gas permeability and respiration rate of the product (Zagory, 1999; Artés et al., 2006; Gavara et al., 2009) and is used for a product for which the use of gas composition different from air is less critical to the final quality and shelf-life, for instance, in whole adult leaves for which browning is not a limiting factor.

Automatic fill-seal systems equipped with gas mixers are commonly used to apply either passive or active MAP. They are made up of vertical or horizontal flow pack systems. The packaging machines are usually made of round vertical tubes wrapped with tubular packaging material. The machine seals first the bottom part of the bag, fills it with the product transported it in the internal part of the tube by using weight-based portion control machines (Gil et al., 2015); after filling the upper part of the bag is sealed. These equipments may also have a gas mixer or filler such that exiting product is flushed with the appropriate gas compositions. The mixture of $\mathrm{O}_{2}, \mathrm{CO}_{2}$ and $\mathrm{N}_{2}$ gases flushed into film packages during form-fill sealing may affect fresh-cut product quality depending on the sealing strength, respiration rate of the product and the packaging film. Generally, modified atmosphere with low $\mathrm{O}_{2}$ and/or high $\mathrm{CO}_{2}$ concentrations, compensated with $\mathrm{N}_{2}$ gas is used. Usually, low $\mathrm{O}_{2}$ and/or high $\mathrm{CO}_{2}$ gas concentrations, decrease the respiration rate of the product, the growth of postharvest pathogens, preserve the visual appearance, maintain nutritional quality, slows down browning process and the rate of deterioration during storage (Kader et al., 1989; Gorny, 2003). Note that low $\mathrm{O}_{2}$ and/or high $\mathrm{CO}_{2}$ as used is in relation to that of normal air, which is about $21 \%$ $\mathrm{O}_{2},<0.03 \% \mathrm{CO}_{2}$ and about $78 \% \mathrm{~N}_{2}$.

$\mathrm{CO}_{2}$ is a colorless gas and has a slightly pungent odor when it is used at very high concentrations, which is valued in the modified atmosphere packaging of foods, due to its bacteriostatic and fungistatic properties. It inhibits the growth of the many spoilage bacteria and the inhibition rate increases with increased $\mathrm{CO}_{2}$ concentrations in the given atmospheres. However for elevated $\mathrm{CO}_{2}$ to be effective against microorganisms, low temperature conditions are required because its solubility decreases with increasing temperature (Sivertsvik et al., 2002). High $\mathrm{CO}_{2}$ modified atmosphere has also been reported to significantly inhibit phenolic accumulation in fresh-cut lettuce and carrots due to the ability to inhibit the phenylalanine ammonia lyase activity (Mateos, 1993; Amanatidou et al., 2000). An equilibrium atmosphere is attained when film permeation rates for $\mathrm{O}_{2}$ and $\mathrm{CO}_{2}$ match the respiration rates of the packaged fresh produce inside a package (Jacxsens et al., 2001; Almenar et al., 2007). This is critical for the success of MAP storage since exposure of fresh produce to too high $\mathrm{CO}_{2}$ levels may cause physiological damages while exposure to too low $\mathrm{O}_{2}$ levels may induce anaerobic respiration and the development of off-fla- vors (Zagory and Kader, 1988; Pesis, 2005; Manolopoulou and Varzakas, 2015). High levels of $\mathrm{CO}_{2}$ may have a deleterious effect on cell membrane and can cause physiological damage, browning reactions, produce off-flavors and increase the aging rates of fruit and vegetable products (Pascall, 2011). As observed by La Zazzera et al. (2012) fresh-cut artichokes stored in air $+25 \% \mathrm{CO}_{2}$ showed a tendency to develop brown spots on the external bracts and higher ammonia accumulation compared to lower $\mathrm{CO}_{2}$ concentrations at the end of 8 days storage at $5^{\circ} \mathrm{C}$.

The optimal atmosphere concentration for most popular cutproducts have been identified (Gorny, 2003), and there are many studies on the effect of gas composition and on packaging optimization for less popular species such as fresh-cut coconut (Amodio et al., 2004); basil leaves (Amodio et al., 2005); rocket salad (Cornacchia et al., 2006); fennels (Rinaldi et al., 2010); fresh-cut pumpkins (Amodio et al., 2010); artichokes (La Zazzera et al., 2015); broccoli raab (Cefola et al., 2016a); zucchini flowers (Cefola et al., 2016b); mushrooms (Capotorto et al., 2015), and peaches (Colantuono et al., 2015). Beside conventional atmospheres, non-conventional gases like argon, nitrous oxide, helium or superoxygen $\left(\mathrm{O}_{2}>20 \%\right.$, generally from 60 to $\left.100 \%\right)$, have emerged they are still being tested (Baldassare et al., 2013; Ansah et al., 2015; Inestroza-Lizardo et al., 2016) and not introduced commercially.

Despite knowing the optimal gas levels for a given product, very often in real conditions, some shifts are observed from desired gas levels and the effective composition obtained at the equilibrium in the package headspace, mainly depending on packaging film and storage temperature (Sandhya, 2010).

The design and selection of the appropriate polymeric films, together with suitable trays, and an appropriate sealing is crucial (Artés et al., 2006). Low-density polyethylene and polypropylene are the main films used for packaging fruits and vegetables (Lee $e t$ al., 1996; Kader and Saltveit, 2003). They contribute to the prevention of desiccation and flaccidity due to vapor barrier properties and reduce the rate of senescence and re-contamination by microorganisms (Brecht et al., 2004). MAP packages are checked periodically for seal integrity in water-filled pressurized chamber. Despite the ample information available on packaging films in the horticultural industry (Lange, 2000), modified atmosphere packaging machines, modes of operation, and different method of gas packaging (Parry, 2012), there is scarce literature on the effects of packaging machines on sealing ability and subsequent quality of fresh-cut products. A typical limitation on produce quality will be the inability of vertical form-fill-seal packaging machines to seal films with narrow sealing ranges without accurate temperature controllers (NIIR Board, 2002). Temperature may, in fact, cause thermal degradation of films, which can lead to suboptimal sealing (Mihindukulasuriya and Lim, 2012). Secondly, the type of heat sealers and film material used in automated packaging may affect the shelf life quality of products. The feasibility of using verticalform-fill with thermal sealers on biodegradable high-density polyethylene (BHDPE) and biodegradable polypropylene was studied by Brown et al. (2009) on fresh-cut romaine lettuce. Seal integrity was not guaranteed for both films performing much worse than the control in conventional polyethylene/oriented polypropilene (PE/OPP). In a second experiment, a hand impulse sealer provided sufficient hermetic conditions for BHDPE bags such that packaged romaine lettuce had similar decay rate and level of pinking after 14 days storage as that of the PE/OPP conventional bags (Brown et al., 2009).

Package sealing integrity and precision can also be compromised by an interference of water from the fresh-cut product itself 
at the film-film interface during the filling process. However, processing parameters of the form-fill-seal machines can help to improve sealing strength when carefully tailored to film characteristics irrespective of water or liquid interference. Mihindukulasuriya and Lim (2012) found that a combination of $165^{\circ} \mathrm{C}$ jaw temperature and $1 \mathrm{~s}$ dwell time was required to form intact seals on water-contaminated linear low-density polyethylene (LLDPE) films, but interface temperature of $130-140^{\circ} \mathrm{C}$ provided the optimal seal strength for both water contaminated and clean LLDPE films. Sealing strength is important to maintain intact modified atmosphere gas conditions for fresh-cut quality. Temperature near the fusion point, but below the melting point is recommended for achieving the highest peel seal strength (Aithani et al., 2006); particularly temperature should ensure that high-molecular-weight and less branched chains began to melt and diffuse across the interface (Mueller et al., 1998). In contrast to welded films, intact seals can be obtained for peelable films at a lower temperature and lower pressure but with longer dwelling times (Baker, 2009). However line speed may directly influence dwelling time; the faster the speed, the shorter the dwelling time (Yuan et al., 2007) and vice versa. Finally, once a processor individuates the packaging material and dimensions for a given product, a variation in the respiration rate of the raw material may lead to unexpected and undesirable gas composition at the equilibrium (Sivertsvik et al., 2002). This may be the case of products having variable respiration with the season, or if different varieties are alternated along the year. Tudela et al. (2013) found that a faster accumulation of $\mathrm{CO}_{2}$ in the headspace of cut-products from immature heads than in over-mature ones, and an extreme variability among different varieties and in different months during the winter-spring seasons. As another example, respiration rate of rocket leaves was found to vary with the season and the number of cutting (first, second, etc.) or maturity (MartínezSánchez et al., 2008; Seefeldt et al., 2012). The same variability has been reported for different variety and time of harvest of broccoli florets (Seefeldt et al., 2012). All these factors suggest that respiration rate is a very critical factor to be monitored before packaging, particularly in the case of different sources of raw materials. Mastrandrea et al. (2017a) showed that when respiration rate is underestimated, the improper gas atmosphere in the packaging can reduce shelf-life of rocket leaves, even if stored at proper temperature $\left(5^{\circ} \mathrm{C}\right)$. In addition, any temperature abuse during transport, distribution and display, will induce an increase of product metabolism dramatically affecting the gas composition within the packaging. Even a short period of temperature abuse can, in fact, be detrimental to the final product quality and shelf-life, enhancing degradative reaction and the growth of microorganisms, with the consequent development of off-odors, as shown for several fresh-cut products (Kou et al., 2014; Luca et al., 2016). Amodio et al. (2015) showed on fresh rocket leaves that an abuse at $13^{\circ} \mathrm{C}$ for 24 hours reduced the product shelf life of about $10 \%$ (from 5.8 to 5.2 days). Moreover the authors also showed that a fluctuation of $5^{\circ} \mathrm{C}$ in the temperature (remaining between 5 and $10^{\circ} \mathrm{C}$ ), could decrease the shelf-life of almost 1 day. In addition Mastrandrea et al. (2017b) found an increase of acetaldehyde and dimethyl sulfide following temperature abuse over storage in MAP of minimally processed rocket leaves, which persisted even when the cold chain was restored. The temperature recommended for storing fresh-cut products packaged in a modified atmosphere is between $0^{\circ} \mathrm{C}$ and $5^{\circ} \mathrm{C}$, but these products are often kept at temperatures of 10 to $12^{\circ} \mathrm{C}$, during display (Oliveira et al., 2010). Such temperature conditions also increase the risk of water condensation within packages due to poor gas exchange between the film, the product and the surrounding environment (Artés et al., 2006).

\section{Conclusions}

This review allowed making the state of the art of available literature assessing the impact of processing operation during minimally processing on quality of fresh-cut produce.

The extent of the damage was shown to vary with the different type of equipments and different operation modes Moreover, while some processing steps as washing and cutting are well studied, less is known about others. Further studies may be aimed to study drying control parameter effect on final quality of cut produce, also in relation to minimizing energy cost. Regarding to packaging, most of the literature focus on gas optimization, and generally of a single species, while when different products are mixed several issues related to compatibility and tolerance thresholds to oxygen and carbon dioxide need to be assessed. Moreover in relation to packaging biological fluctuation of respiration rate of raw material should be better investigated. Finally, while the impact of processing on sensorial and microbial quality has been more extensively covered, the studies on those effects on phytonutrient retention are less abundant and thus need more investigation.

\section{References}

Abe K., Tanase M., Chachin K. 1998. Studies on physiological and chemical Changes of Fresh-Cut Bananas. I.: Effect of cutting modes on the changes of physiological activity and deterioration in fresh-cut green tip bananas J. Japan. Soc. Hort. Sci. 67:123-9.

Abid M., Gibert R., Laguerie C. 1990. An experimental and theoretical analysis of the mechanisms of heat and mass transfer during the drying of corn grains in a fluidized bed. Int. Chem. Eng. 30:632-42.

Aguayo E., Escalona V., Artés F. 2004. Metabolic behaviour and quality changes of whole and fresh processed melon. J. Food Sci. 69:149-55.

Ahvenainen R. 2000. Ready-to-use fruit and vegetables. Teagasc, The National Food Centre, Dunsinea, Castleknock, Ireland, pp $1-31$.

Aithani D., Lockhart H., Auras R., Tanprasert K. 2006. Predicting the Strongest Peelable Seal for 'Easy-Open'Packaging Applications. J. Plastic Film. Sheet. 22:247-63.

Allende A., Selma M.V., López-Gálvez F., Villaescusa R., Gil M.I. 2008. Role of commercial sanitizer and washing systems on epiphytic microorganisms and sensory quality of fresh-cut escarole and lettuce, Postharvest Biol. Technol. 49:155-63.

Almenar E., Del-Valle V., Hernández-Muñoz P., Lagarón J.M., Catalá R. Gavara, R. 2007. Equilibrium modified atmosphere packaging of wild strawberries. J. Sci. Food Agric. 87:1931-9.

Amanatidou A., Slump R.A., Gorris L.G.M., Smid E.J. 2000. High oxygen and high carbon dioxide modified atmospheres for shelf life extension of minimal processed carrots. J. Food Sci. 65:61-6.

Amodio M.L., Derossi A., Mastrandrea, L., Colelli, G. 2015. A study of the estimated shelf life of fresh rocket using a non-linear model. J. Food Eng. 150:19-28.

Amodio M.L., Peri G., Colelli G., Centonze D., Quinto M. 2005. Effects of atmosphere composition on postharvest quality of fresh basil leaves (Ocimum basilicum L.). Acta Hortic. 682:731-6.

Amodio M.L., Peri G., Romaniello R., Colelli G. 2004. Conservazione in atmosfera modificata di noce di cocco fresca in pezzi. Italus Hort. 11:127-30. 
Amodio M.L., Rinaldi R., Colelli G. 2010. Extending shelf-life of fresh-cut pumpkin (Cucurbita maxima): effect of pre-treatments and storage conditions. Acta Hortic. 876:333-40.

Ansah F.A., Amodio M.L., Colelli G. 2015. Evaluation of the Impact of Nitrous oxide use on Quality and Shelf life of Packaged Fresh-cut 'Iceberg'Lettuce and Wild Rocket. Chem. Eng. 44.

Artés F., Artés-Hernández F. 2003. Etapas decisivas y diseňo de instalaciones para la elaboraciòn de productos procesados en fresco. In: Lobo, M.G., González, M. (Eds.), Productos hortofrutıcolas minimamente procesados. Gobierno de Canarias, pp. 57-78.

Artés F., Gómez P. A. Artés-Hernández F. 2006. Modified atmosphere packaging of fruits and vegetables. Stewart Postharvest. Rev. 2:1-13.

Artes-Hernandez F., Gomez P.A., Artes F. 2013. Unit processing operations in the fresh-cut horticultural product industry: quality and safety preservation. In: G.P.P. Lima, F. Vianello (Eds.) Food Quality, Safety and Technology. Springer, Vienna, pp. 35-53.

Artés-Hernández F., Rivera-Cabrera F., Kader A.A. 2007. Quality Retention and Potential Shelf-Life of Fresh-Cut Lemons as Affected by Cut Type and Temperature. Postharvest. Biol. Technol. 43:245-54.

Baert L., Vandekinderen I., Devlieghere F., Van Coillie E., Debevere J., Uyttendaele M. 2009. Efficacy of sodium hypochlorite and peroxyacetic acid to reduce murine norovirus 1, B40-8, Listeria monocytogenes, and Escherichia coli O157: $\mathrm{H} 7$ on shredded iceberg lettuce and in residual wash water. J. Food Prot. 72:1047-54.

Bajwa U., Sandhu K.S. 2014. Effect of handling and processing on pesticide residues in food - A review. J. Food Sci. Technol. 51:201-20.

Baker M. 2009. Analysis of peelable film in food packaging: 200809. Italian Packaging Technology Awards Program, Department of Packaging Science, Clemson University.

Baldassarre V., Amodio M.L., De Chiara M.L., Colelli G. 2013. Effect of argon-enriched atmospheres on shelf life of fresh-cut iceberg lettuce. In XI International Controlled and Modified Atmosphere Research Conference. Acta Hortic. 1071:755-61.

Bansal V., Siddiqui M.W., Rahman M.S. 2015. Minimally Processed Foods: Overview. In: M.W. Siddiqui, M.S. Rahman (Eds.) Minimally Processed Foods. Springer International Publishing, New York, pp 1-15.

Barry $\square$ Ryan C., O'Beirne D. 1998. Quality and shelf $\square$ life of fresh cut carrot slices as affected by slicing method. J. Food Sci. 63:851-6.

Barry $\square$ Ryan C., O'Beirne D. 1999. Ascorbic acid retention in shredded iceberg lettuce as affected by minimal processing. J. Food Sci. 64:498-500.

Beltrán D., Selma M.V., Tudela J.A., Gil M.I. 2005. Effect of different sanitizers on microbial and sensory quality of fresh-cut potato strips stored under modified atmosphere or vacuum packaging. Postharvest Biol. Technol. 37:37-46.

Brecht J.K., Saltveit M.E., Talcott S.T., Schneider K.R., Felkey K. Bartz J.A. 2004. Fresh-cut vegetables and fruits. Hort. Rev. 30:185-251.

Brown J.W., Vorst K., Palmer S., Singh J.A. 2009. Performance of Pre-Cut Lettuce Packaged in Biodegradable Film Formed on Commercial Vertical-Form-Fill-and-Seal Machines. Industrial Technol. 8.

Buchholz A.L., Davidson G.R., Marks B.P. Todd E.C.D. Ryser E.T. 2012. Quantitative transfer of Escherichia coli O157:H7 to equipment during small-scale production of fresh-cut leafy greens. J. Food Prot. 75:1184-97.

CAC (Codex Alimentarius Commission). 2003. Code of hygienic practice for fresh fruits and vegetables. CAC/RCP 53-2003. Adopted 2003. Revision 2010 (new Annex III for Fresh Leafy Vegetables). Available from: http://www.fao.org/input/download/standards/10200/CXP_053e.pdf Accessed: April, 2017.

Cantwell M., Suslow T. 1999. Fresh-cut fruits and vegetables: aspects of physiology, preparation and handling that affect quality. In: Annual Workshop Fresh-Cut Products: Maintaining Quality and Safety, 5:1-2.

Cantwell M.I., Melo A.A.M., Hong G. Klose S. 2016. Quality of waterjet-and blade-cut romaine salad. In: III International Conference on Fresh-Cut Produce: Maintaining Quality and Safety. Acta Hortic. 1141:153-8.

Capotorto I., Amodio M.L. Colelli, G. 2015. Influence of modified atmosphere packaging on shelf-life of whole and sliced 'Cardoncello' mushroom (Pleurotus eryngii). Acta Hortic. 1079:553-9.

Castro-Ibáñez I., Gil M.I., Allende A. 2016. Ready-to-eat vegetables: Current problems and potential solutions to reduce microbial risk in the production chain, LWT-Food Sci. Technol. 1-9.

Cefola M., Amodio M.L., Colelli G. 2016a. Design of the correct modified atmosphere packaging for fresh-cut broccoli raab. Acta Hortic. 1141:117-22.

Cefola M., Amodio M.L., Colelli G. 2016b. Extending postharvest life of ready-to-use zucchini flowers: effects of the atmosphere composition. Acta Hortic. 1141:123-30.

Cisneros-Zevallos L., Jacobo-Velázquez D.A., Pech J.C., Koiwa H. 2014. Signaling Molecules Involved in the Postharvest Stress Response of Plants. In: M. Pessarakli (Ed.) Handbook of Plant and Crop Physiology. Third Edition. CRC press, Boca Raton, FL, USA, pp. 259-276.

Colantuono F., Amodio M.L. Colelli G. 2015. Comparison of different gas compositions on fresh-cut peach quality: a preliminary study. Acta Hortic. 1071:763-70.

Cornacchia R., Rinaldi R., Quinto M., Colelli G. 2006. Effetto della conservazione in atmosfera controllata (AC) sugli attributi qualitativi di foglie di rucola. Colture Prot. 35:32-8.

Curcio S., Aversa M., Chakraborty S., Calabrò V., Iorio G. 2016. Formulation of a 3D conjugated multiphase transport model to predict drying process behavior of irregular-shaped vegetables. J. Food Eng. 176:36-55.

Deza-Durand K.M., Petersen M.A. 2011. The Effect of Cutting Direction on Aroma Compounds and Respiration Rate of Fresh-Cut Iceberg Lettuce (Lactuca Sativa L.). Postharvest Biol. Technol. 61:83-90.

FDA/CFSAN. 2008. Guidance for Industry: Guide to Minimize Microbial Food Safety Hazards of Fresh-Cut Fruits and Vegetables. Available from: http://www.fda.gov/food/guidancecomplianceregulatoryinformation/guidancedocuments/pr oduceandplanproducts/ucm064458.htm

Gavara R., Catala R. Hernandez-Munoz P. 2009. Extending the shelf-life of fresh-cut produce through active packaging. Stewart Postharvest Rev. 4:1-5.

Gil M.I., Selma M.V., López-Gálvez F., Allende A. 2009. Fresh-cut product sanitation and wash water disinfection: problems and solutions. Int. J. Food Microbiol. 134:37-45.

Gil M.I., Selma M.V., Suslow T., Jacxsens L., Uyttendaele M., Allende, A. 2015. Pre-and postharvest preventive measures and intervention strategies to control microbial food safety hazards of fresh leafy vegetables. Crit. Rev. Food Sci. Nutr. $55: 453-68$ 
Giovenzana V., Beghi R., Civelli R., Guidetti R. 2015. Optical techniques for rapid quality monitoring along minimally processed fruit and vegetable chain. Trends Food Sci. Techn. 46:331-8.

Gómez-López V.M., Devlieghere F., Ragaert P., Debevere J. 2007. Shelf-life extension of minimally processed carrots by gaseous chlorine dioxide. Int. J. Food Microbiol. 116:221-7.

Gómez-López V.M., Marín A., Medina-Martínez M.S., Gil M.I., Allende A. 2013. Generation of trihalomethanes with chlorinebased sanitizers and impact on microbial, nutritional and sensory quality of baby spinach. Postharvest Biol. Technol. 85:210-7.

Gonzalez R.J., Luo Y., Ruiz-Cruz S., McEvoy J.L. 2004. Efficacy of sanitizers to inactivate Escherichia coli O157:H7 on freshcut carrot shreds under simulated process water conditions. J. Food Prot. 67:2375-80.

Gorny J.R. 2003. A summary of CA and MA requirements and recommendations for fresh-cut (minimally processed) fruits and vegetables. Acta Hortic. 600:609-14.

Gorny J.R., Hess-Pierce B., Cifuentes R.A., Kader A.A. 2002. Quality changes in fresh-cut pear slices as affected by controlled atmospheres and chemical preservatives. Postharvest Biol. Technol. 24:271-8.

Grout B., Akrivousi A., Makwabara S. Bishop C. 2002. Interactions between Knife Sharpness and Storage Temperature on Browning at the Cut Surface of HandTrimmed Bobby Beans (Phaseolus vulgaris). In: International Conference: Postharvest Unlimited 599:129-32.

Hernandez-Brenes C. 2002. Good manufacturing practices for good handling, packing, storage and transportation of fresh produce. In: Improving the safety and quality of fresh fruits and vegetables: a training manual for trainers. JIFSAN, University of Maryland, 3:1-34.

Holvoet K., Jacxsens L., Sampers I., Uyttendaele M. 2012. Insight into the prevalence and distribution of microbial contamination to evaluate water management in the fresh produce processing industry. J. Food Prot. 75:671-81.

Inestroza-Lizardo C., Silveira A.C., Escalona V.H. 2016. Metabolic activity, microbial growth and sensory quality of arugula leaves (Eruca vesicaria Mill.) stored under non-conventional modified atmosphere packaging. Sci. Hortic. 209:79-85.

Izumi H., Watada A.E., Ko N.P., Douglas W. 1996. Controlled atmosphere storage of carrot slices, sticks and shreds. Postharvest Biol. Technol. 9:65-172.

Jacxsens L., Devlieghere F., Ven der Steen C., Devebere J. 2001. Effect of high oxygen modified atmosphere packaging on microbial growth and sensorial qualities of fresh-cut produce. Int. J. Food Microbiol. 71:197-210.

Kader A.A 2002. Postharvest technology of horticultural crops. Coop. Extension. Service. University of California. Special Publication. 3311. Agricultural and Natural Resources Publication, Berkley, CA, USA, pp. 99-102.

Kader A.A., Saltveit M.E. 2003. Respiration and gas exchange. In: J.A. Bartz, J.K. Brecht (Eds.) Postharvest physiology and pathology of vegetables. Marcel Dekker Inc., New York, USA, pp. 7-29.

Kader A.A., Zagory D., Kerbel E.L., Wang C.Y. 1989. Modified atmosphere packaging of fruits and vegetables. Crit. Rev. Food Sci. Nutr. 28:1-30.

Kim J-G., Yousef A.E., Chism G.W. 1999. Use of ozone to inactivate microorganisms on lettuce. J. Food Saf. 19:17-34.

Kim S-W., Abd El-Aty A.M., Choi J-H., Lee Y-J., Lieu T.T.B., Chung H.S., Rahman Md. M., Choi O-J., Shin H-C., Rhee G-
S., Chang M-I., Kim H.J., Shim J-H. 2016. Contribution effects of various washing procedures and additives on the decline pattern of diethofencarb in crown daisy, a model of leafy vegetables. Food Chem. 201:153-9.

Kou L., Luo Y., Park E., Turner E.R., Barczak A., Jurick, W.M. 2014. Temperature abuse timing affects the rate of quality deterioration of commercially packaged ready-to-eat baby spinach. Part I: Sensory analysis and selected quality attributes. Postharvest Biol. Technol. 91:96-103.

La Zazzera M., Amodio M.L., Colelli G. 2015. Designing a modified atmosphere packaging (MAP) for fresh-cut artichokes. Adv. Hort. Sci. 29:24-9.

La Zazzera M., Rinaldi R., Amodio M.L., Colelli G. 2012. Influence of high $\mathrm{CO} 2$ atmosphere composition on fresh-cut artichoke quality attributes. Acta Hortic. 934: 633-40.

Lange D.L. 2000. New film technologies for horticultural products. Hort. Technol. 10:487-90.

Lee L., Arul J., Lencki R., Castaigne F. 1996. A review on modified atmosphere packaging and preservation of fresh fruits and vegetables: physiological basis and practical aspects-part II. Packag. Technol. Sci. 9:1-17.

Lee Y.R., Kim S.T., Choe M.G., Moon K.D. 2008. Effect of different types of cutting on the quality of fresh-cut sweet pumpkin (Cucurbita maxima Duchesne). Korean J. Food Preserv. 15:191-6.

Lopez-Fernandez R., Rial-Otero O., Simal Gandara J. 2013. Factors governing the removal of mancozeb residues from lettuces with washing solutions. Food Control 34:530-8.

López-Gálvez F., Allende A., Selma M.V., Gil M.I. 2009. Prevention of Escherichia coli cross-contamination by different commercial sanitizers during washing of fresh-cut lettuce. Int. J. Food Microbiol. 133:167-71.

López-Gálvez F., Gil M.I., Truchado P., Selma M.V., Allende A. 2010. Cross contamination of fresh-cut lettuce after a shortterm exposure during pre-washing cannot be controlled after subsequent washing with chlorine dioxide or sodium hypochlorite. Food Microbiol. 27:199-204.

Luo Y. 2007. Challenges facing the industry and scientific community in maintaining quality and safety of fresh-cut produce. Acta Hortic. 746:213-22.

Luo Y., Nou X., Yang Y., Alegre I., Turner E., Feng H., Abadias M., Conway W. 2011. Determination of free chlorine concentrations needed to prevent Escherichia coli O157: H7 cross-contamination during fresh-cut produce wash. J. Food Prot. $74: 352-8$

Mangaraj S., Goswami T.K., Mahajan P.V. 2009. Applications of plastic films for modified atmosphere packaging of fruits and vegetables: a review. Food Eng. Rev. 1:133.

Manolopoulou E., Varzakas T. 2015. Modified atmosphere packaging of fruits and vegetables. In: T. Varzakas, C. Tzia (Eds.) Handbook of Food Processing: Food Preservation 34. Taylor and Francis Group, CRC Press, Boca Raton, FL, USA, pp 651-674.

Martínez-Sánchez A., Allende A., Bennett R. N., Ferreres F., Gil M.I. 2006. Microbial, nutritional and sensory quality of rocket leaves as affected by different sanitizers. Postharvest Biol. Technol. 42:86-97.

Martínez-Sánchez A., Allende A., Cortes-Galera Y., Gil M.I. 2008. Respiration rate response of four baby leaf Brassica species to cutting at harvest and fresh-cut washing. Postharvest Biol. Technol. 47:382-8.

Mastrandrea L., Amodio M.L., de Chiara M.L.V., Pati S., Colelli G. 2017a. Effect of temperature abuse and improper atmosphere packaging on volatile profile and quality of rocket 
leaves. Food Packag. Shelf Life 14:59-65.

Mastrandrea L., Amodio M.L., Pati S., Colelli G. 2017b. Effect of modified atmosphere packaging and temperature abuse on flavor related volatile compounds of rocket leaves (Diplotaxis tenuifolia L.). J. Food Sci. Technol. 1-10.

Mateos M., Ke D., Cantwell M., Kader A.A. 1993. Phenolic metabolism and ethanolic fermentation of intact and cut lettuce exposed to $\mathrm{CO}_{2}$-enriched atmospheres. Postharvest Biol. Technol. 3:225-33.

Matthews K.R. 2013. Sources of enteric pathogen contamination of fruits and vegetables: future directions of research. Stewart Postharvest Rev. 9:1-5.

Mcglynn W.G., Bellmer D.D. and Reilly S.S. 2003, Effect of precut sanitizing dip and water jet cutting on quality and shelflife of fresh-cut watermelon. J. Food Qual. 26:489-98.

Mihindukulasuriya S., Lim L.-T. 2012. Effects of Liquid Contaminants on Heat Seal Strength of low-density polyethylene Film. Packag. Technol. Sci. 25:271-84.

Mishra B.B., Gautam S., Sharma A. 2012. Browning of Fresh-Cut Eggplant: Impact of Cutting and Storage. Postharvest Biol. Technol. 67:44-51.

Moretti C.L., Mattos L.M., Machado C.M.M., Kluge R.A. 2007. Physiological and quality attributes associated with different centrifugation times of baby carrots. Hortic. Bras. 25:557-61.

Mueller C., Capaccio G., Hiltner A., Baer. E. 1998. Heat sealing of LLDPE: relationships to melting and interdiffusion. J. Appl. Polym. Sci. 70:2021-30.

Nagaya K., Li Y., Jin Z., Fukumuro M., Ando Y., Akaishi A. 2006. Low-temperature desiccant-based food drying system with airflow and temperature control. J. Food Eng. 75:71-7.

Naidu M.M., Vedashree M., Satapathy P., Khanum H., Ramsamy R., Hebbar H.U. 2016. Effect of drying methods on the quality characteristics of dill (Anethum graveolens) greens. Food Chem. 192:849-56.

Negi P.S., Roy S.K. 2001. Effect of drying conditions on quality of green leaves during long term storage. Food Res. Int. 34:283-7.

Nicola S., Tibaldi G., Fontana E. 2009. Fresh-cut produce quality: Implications for a systems approach. In: W.J. Florkowski, R.L. Shewfelt, B. Brueckner, S.E. Prussia (Eds.) Postharvest handling. Academic Press, New York, NY, USA, pp 247-282.

NIIR Board 2002. Handbook on Modern Packaging Industries. Asia Pacific Business Press, Inc.

O'Beirne D. 1995. Influence of raw material and processing on quality of minimally processed vegetables. Improvement of the safety and quality of refrigerated ready-to-eat foods using novel mild preservation techniques. Progress Highlight C/95.

Olaimat A.N., Holley R.A. 2012. Factors influencing the microbial safety of fresh produce: a review. Food Microbiol. 32:1-19.

Oliveira M., Usall J., Solsona C., Alegre I., Vinas I., Abadias M. 2010. Effects of packaging type and storage temperature on the growth of foodborne pathogens on shredded 'Romaine' lettuce. Food Microbiol. 27:375-80.

Parry R.T. (Ed.) 2012. Principles and applications of modified atmosphere packaging of foods. Springer Science \& Business Media.

Pascall M.A. 2011. The packaging of nutraceuticals derived from plants. In: Y. Pathak (ed.) Handbook of Nutraceuticals Volume II: Scale-Up, Processing and Automation, 2. CRC press, Boca Raton, FL, USA, pp 313-346.

Paull R.E. 1999. Effect of temperature and relative humidity on fresh commodity quality. Postharvest Biol. Technol. 15:263-77.

Pesis E. 2005. The role of the anaerobic metabolites, acetaldehyde and ethanol, in fruit ripening, enhancement of fruit quality and fruit deterioration. Postharvest Biol. Technol. 37:1-19.

Portela S.I., Cantwell M.I. 2001. Cutting Blade Sharpness Affects Appearance and Other Quality Attributes of Fresh-Cut Cantaloupe Melon. J. Food Sci. 66:1265-70.

Rinaldi R., Amodio M.L., Colelli G. 2010. Effetto dell'atmosfera controllata sull'aspetto esteriore del finocchio (Foeniculum vulgare Mill. Subsp. vulgare var. azoricum (MIll.) Thell.) di IV gamma. Italus Hort. 17:68-71.

Rux G., Caleb O.J., Geyer M., Mahajan P.V. 2017. Impact of water rinsing and perforation-mediated MAP on the quality and offodour development for rucola. Food Packag. Shelf Life. 11:21-30.

Saavedra del Aguila J., Sasaki F.F., Heiffig L.S., Ortega E.M.M., Jacomino A.P., Kluge R.A. 2006. Fresh-cut radish using different cut types and storage temperatures. Postharvest Biol. Technol. 40:149-54.

Sandhya. 2010. Modified atmosphere packaging of fresh produce: Current status and future needs. LWT - Food Sci. Technol 43:381-92.

Sanz S., Gimenez M., Olarte C., Lomas C., Portu J. 2002. Effectiveness of chlorine washing disinfection and effects on the appearance of artichoke and borage. J. Appl. Microbiol. 93:986-93.

Sapers G.M. 2003. Washing and sanitizing raw materials for minimally processed fruit and vegetable products. In: J.S. Novak, G.M. Sapers, V.K. Juneja (Eds.) Microbial safety of minimally processed foods. CRC Press, Boca Raton, FL, London, New York, Washington, DC, pp 221-253.

Seefeldt H.F., Løkke M.M., Edelenbos M. 2012. Effect of variety and harvest time on respiration rate of broccoli florets and wild rocket salad using a novel $\mathrm{O}_{2}$ sensor. Postharvest Biol. Technol. 69:7-14.

Sivertsvik M., Rosnes J.T., Bergslien H. 2002. Modified atmosphere packaging. In: T. Ohlsson, N. Bengtsson (Eds.) Minimal processing technologies in the food industry. Woodhead publishing, UK, pp 61-86.

Soliva-Fortuny R.C., Martín-Belloso O. 2003. New advances in extending the shelf-life of fresh-cut fruits: a review. Trends Food Sci. Technol. 14:341-53.

Surjadinata B.B., Cisneros-Zevallos L. 2003. Modeling woundinduced respiration of fresh-cut carrots (Daucus carota L.). J. Food Sci. 68:2735-40.

Toivonen P., Stan S. 2004. The effect of washing on physicochemical changes in packaged, sliced green peppers. Int. J. Food Sci. Technol. 39:43-51.

Tomás-Callejas A., López-Gálvez F., Sbodio A., Artés F., ArtésHernández F., Suslow T.V. 2012. Chlorine dioxide and chlorine effectiveness to prevent Escherichia coli O157: H7 and Salmonella cross-contamination on fresh-cut Red Chard. Food Control. 23:325-332.

Tudela J.A., Marín A., Martínez-Sánchez A., Luna M.C., Gil M.I. 2013. Preharvest and postharvest factors related to off-odors of fresh-cut iceberg lettuce. Postharvest Biol. Technol. 86:463-71.

Turatti A. 2015. Innovations in fresh-cut fruit process lines. In: III International Conference on Fresh-Cut Produce: Maintaining Quality and Safety 1141:21-34.

Turatti A. 2011. Process design, facility and equipment requirements. In: Advances in Fresh-Cut Fruits and Vegetables Processing. Food Preservation Technology Series. CRC Press, Taylor \& Francis Group, pp. 339-361.

Van Loey A., Smout C., Hendrickx M. 2005. Kinetic data for biochemical and microbiological processes during thermal processing. In: M.A. Rao, S.S.H. Rizvi, A.K. Datta (Eds.), Engineering Properties of Foods, Third Edition. CRC Press, 
Taylor \& Francis, Boca Raton, FL, USA, pp. 611-643.

Vandekinderen I., Devlieghere F., De Meulenaer B., Ragaert P., Van Camp J. 2009. Optimization and evaluation of a decontamination step with peroxyacetic acid for fresh-cut produce. Food Microbiol. 26:882-8.

Vandekinderen I., Van Camp J., De Meulenaer B., Veramme K., Denon Q., Ragaert P., Devlieghere F. 2007. The effect of the decontamination process on the microbial and nutritional quality of fresh-cut vegetables. Acta Hortic. 746:173-80.

Wulfkuehler S., Stark S., Dietz J. 2014. Effect of Water Jet Cutting and Moderate Heat Treatment on Quality of Fresh-
Cut Red Oak Leaf Lettuce (Lactuca sativa L. var. crispa). Food Bioprocess Technol 7:3478-92.

Yuan C.S., Hassan A., Ghazali M.I.H., Ismail A.F. 2007. Heat sealability of laminated films with LLDPE and LDPE as the sealant materials in bar sealing application. J. Appl. Polym. Sci. 104:3736-45.

Zagory D. 1999. Effects of post-processing handling and packaging on microbial population. Postharvest Biol. Technol. 15:313-21.

Zagory D., Kader A.A. 1988. Modified atmosphere packaging of fresh produce. Food Technol. 9:70-7. 